\title{
The Other Partner: The Changing Role of Good Provider for Men's Union Formation in Industrialized Countries
}

\author{
Frances Goldscheider \\ Dennis Hogan \\ Brown University \\ Providence, Rhode Island, USA \\ Pierre Turcotte \\ Statistics Canada \\ Ottawa, Ontario, Canada
}

\begin{abstract}
Most studies of union formation behaviors have focused on women and children, with less emphasis on men. Using comparable retrospective survey data, this study looks at the ways Canadian, Italian and Swedish men begin conjugal life (distinguishing between marriage and cohabitation) and at how the effects of their good provider status qualifications have changed in the last 30 years. Results for Canadian men have shown that the simple patterns that have been assumed to shape separate and symmetrical roles for men and women are taking new shapes with the growth in cohabitation and changes in women's economic roles. Our study will extend these results to examine two countries at very different levels of cohabitation prevalence: Italy, where the growth in cohabitation has just begun, and Sweden, where it has been underway much longer than in Canada. Our results show strongly parallel changes underway in each country, indicating that it is important to continue to compare, both between countries and over time, if we are to understand the situations fostering (or not) changing gender roles for men as good providers.
\end{abstract}

Key Words: Male provider, cohabitation, gender roles 
Francis Goldscheider, Dennis Hogan and Pierre Turcotte

\section{Résumé}

La plupart des études sur les comportements durant le passage à la vie de couple ont porté sur les femmes et les enfants, avec moins d'emphase sur le comportement des hommes. En se servant de données comparables d'enquêtes rétrospectives, cet article examine les différentes façons dont les Canadiens, les Italiens et les Suédois commencent leur vie conjugale (en distinguant entre le mariage et la cohabitation) ainsi que les effets causés par les changements des trente dernières années dans leur statut de pourvoyeur. Chez les Canadiens, les résultats démontrent que les habitudes de vie qui avaient été prises pour modeler des rôles masculins et féminins séparés et symétriques sont en train de prendre de nouvelles formes, avec une croissance dans les taux de cohabitation et des changements dans les rôles économiques des femmes. Notre étude élargira ces résultats pour examiner deux autres pays où existent des taux de cohabitation très différents : L'Italie, où la croissance de la cohabitation vient de débuter et la Suède, où elle existe depuis bien plus longtemps qu'au Canada. Nos résultats démontrent que des changements très parallèles sont en cours dans chacun des deux pays ce qui indique qu'il est important de continuer à comparer, et entre les pays et dans la durée, pour pouvoir comprendre les situations qui engendrent (ou non) des changements dans le rôle de pourvoyeur joué par les hommes.

Mots-clés: Le rôle de pourvoyeur, la cohabitation, les rôles sexuels

\section{Introduction}

That men's ability to support a family is the normal requirement for marriage in western, industrialized countries has been accepted by family theorists for two centuries. Men have the "good provider" role in the family (Bernard, 1981). Empirical evidence from these countries has largely supported this assumption (see, for example, Blom, 1994; Bracher and Santow, 1998; Corijn and Klijzing, 2001; Huinink, 1995; Santow and Bracher, 1994). This is also the case for research on the United States for the nineteenth and most of the twentieth century (see, for example, Goldscheider and Waite, 1986; Hogan, 1978; Landale, 1989; Mare and Winship, 1991). This understanding has led some scholars to interpret the delay in marriage since the 1970s as the result of young men's increased difficulty attaining the economic status to marry (see, for example, Mills, Blossfeld and Klijzing 2005; Oppenheimer, 1988; Oppenheimer et al., 1995, 1996; Wilson, 1987, 1997). Changes in the timing and types of 


\section{The Other Partner: The Changing Role of Good Provider for Men's Union Formation in Industrialized Countries}

unions formed over the last few decades, however, require us to reexamine this premise in the closing years of the twentieth century.

Perhaps fundamentally, the union formation process itself has recently been transformed. Cohabitation is increasing throughout the western, industrialized world, which involves less commitment than marriage (Bumpass, Sweet and Cherlin, 1991), and possibly requires less of men as good providers. With increasing education and higher labor force participation, women's roles outside the family have also changed dramatically, as they have added providing to their role repertoire (Spain and Bianchi, 1996).

These changes challenge our theories of family life. Are there connections among these new trends? Has the rise in female employment simply meant that there is now pressure to provide on both men and women, as seems to be the case in Sweden (Bracher and Santow, 1998)? Other research on Sweden, Italy, Canada and the United States suggests that increasingly, it is women with the highest earnings or earnings potential who marry (Goldscheider, Turcotte and Kopp, 2001; Sweeney, 2002). This is a significant change for the United States from the time when it was more educated women, the "cream of the crop" as Bernard (1972) called them, who avoided marriage either by not entering or dissolving unions at a higher rate than women with less education.

Such a change in the effects of women's education on marriage formation suggests that women's increased economic prowess may not only have provided them the independence to avoid traditional family roles, but also have allowed men to enter unions with less pressure to "provide." Or with young adults now more accepting of remaining single and cohabiting (Thornton, 2001), marriage and its roles may not have changed, but instead have simply less available to all, open primarily to the most successful, a luxury item (Furstenberg 1996).

There are relatively few studies of changes in the factors influencing men's marital timing, as most studies of men have not dealt systematically or comparatively with change. The purpose of this paper is to look at these factors influencing men's union formation in three western, industrialized countries and to examine whether and if so how the effects of some of these factors have changed between the 1960s and the early 1990s. We use data collected at about the same time, using comparable questions, but that also allow us to examine change within each country over about a 20 -year period.

We consider Canada, Italy and Sweden. If there is, in fact, a general process of change underway, as theorists of the "Second Demographic Transition" suggest (van de Kaa, 1987), these countries should allow us to analyze an important part of the range of changes. Sweden and Italy are at the high and low ends in terms 
Francis Goldscheider, Dennis Hogan and Pierre Turcotte

of the prevalence of cohabitation in European countries, and Canada is intermediate, but undergoing rapid change on this dimension (Statistics Canada, 2002; Le Bourdais and Marcil-Gratton, 1996). To examine cohort change, we will focus our analysis particularly on examining changes in the effects of education, the central measure of human capital and hence, the key to the good provider role. We ask: What is the connection between men's educational level and marriage in these three countries and has it changed between the 1970s and the 1990s? In other words, has the meaning of a good provider changed? And how has the new option of cohabitation affected the process of union entry for men?

\section{Research on Men's Union Formation}

Most previous studies on union formation that have considered men at all have focused predominantly on men's support capabilities, i.e., their ability to provide for women and children, and done so primarily as a characteristic of the communities in which women live. For example, research on women has shown that differences in the availability of partners, and particularly high quality partners, strongly affect women's likelihood of marrying (Lichter et al., 1992; Lichter and Anderson, 1995). Only a few studies have evaluated men's marriage and cohabitation from the perspective of men themselves, making them, their attitudes and goals, and their preferences and constraints, the focus of the analysis (e.g., Corijn and Klijzing, 2001; Goldscheider and Waite, 1991; Oppenheimer, 2003).

In most societies, men marry later than women, largely because they are traditionally responsible for supporting their households. In societies that share the household system of northwestern Europe (Hajnal, 1982; Wall, 1983), most men became heads of their own household upon marriage. When conditions were favorable for setting up new households, men (and women) married early, and research on men's union formation supports this (Blom, 1994; Dixon, 1978). Sweden and Canada share this heritage, and in each country, there is evidence that economic ability increases men's likelihood of union formation (Bracher and Santow, 1998; Turcotte and Goldscheider, 1998). Based on pre$20^{\text {th }}$ century patterns, Italy was placed outside the area of the western European household system (Hajnal, 1962), but there are strong expectations among modern Italian men that union formation should be delayed until economic and residential independence (Castiglioni and Dalla Zuanna, 1994) and the evidence on their union formation patterns supports this (Ongaro, 2001).

Nevertheless, what constitutes being a good provider is likely to vary depending on the type of union being formed. In research on the United States, recent 


\section{The Other Partner: The Changing Role of Good Provider for Men's Union Formation in Industrialized Countries}

analyses show that employment continues to increase men's likelihood of marrying (Lloyd and South, 1996; Sassler and Schoen, 1999; Sweeney, 2002), although it may reduce the likelihood of cohabiting (Clarkberg, Stolzenberg, and Waite, 1995). Irregular work histories increase men's probability of forming cohabiting unions rather than marriages (Clarkberg, 1999). Nonetheless, men's earnings are positively associated with entry into both marriage and cohabitation (Clarkberg, 1999). Hence, there is some suggestion that the growth in cohabitation has decreased men's need to be good providers, but the issue is far from clear. Research on the effects of educational attainment on union formation in Europe that compare entry to cohabiting and marital unions is also not clear. More education, controlling for enrolment, increases German men's likelihood of entry into marriage, but has no effect on overall union formation, suggesting that education might have a negative effect on entering cohabiting unions in Germany (Hullen 2001). However, there is no effect of educational attainment on men's entry into either all unions or marital unions in the Netherlands (Corijn, 2001) or in Flanders. ${ }^{1}$

There is increasing evidence, however, that the importance of men's provider status for marriage formation might have declined in the United States between the 1970s and the 1990s. In particular, the importance of being employed appears to have lessened (Sassler and Goldscheider 2004; Sweeney, 2002). What cannot be assessed from these studies, however, is whether these patterns observed in the United States are more general in the industrialized west, and hence perhaps part of the second demographic transition (van de Kaa, 1987).

We use men's educational attainment as a proxy for permanent income and earnings potential, and hence the most general indicator of the ability to provide. In Norway men with higher educational levels were more likely to marry than their less educated counterparts (Blom, 1994) and a similar pattern was observed in the U.S. (Hogan, 1978; Mare and Winship, 1991). Educational attainment has a more complex effect on cohabitation. Although the more educated appear to have led the early growth in cohabitation in Norway and the U.S., the acceleration of cohabitation was most rapid for those with less schooling (Blom, 1994; Bumpass et al., 1991); by the late 1980s, educational attainment had become strongly and negatively related to cohabitation before first marriage (Bumpass and Sweet, 1989). In order to test the effects of educational attainment, however, it is necessary to control for school enrollment. Although an indicator of future earnings capacity, enrollment generally deters both marriage and cohabitation, reflecting its immediate impact on current activities and earnings (Clarkberg, 1999; Thornton et al., 1995).

During the same period that cohabitation began to increase, changes in the economy linked with globalization have reduced the employment prospects of 
Francis Goldscheider, Dennis Hogan and Pierre Turcotte

many young men (Mayer, 2001; Levy, 1995), reshaping the context in which young men make union decisions. Men's median age at marriage increased in most countries (Corijn and Klijzing 2001). Despite increases in schooling, the additional years of schooling alone do not account for the extent of marital delay in the United States (Mare and Winship, 1991). If good economic prospects are still necessary for men to marry, these trends suggest that men in the late $20^{\text {th }}$ century will have difficulty entering unions.

This same period, of course, has also seen the emerging gender revolution, which might be changing the terms under which men and women enter unions. Previous research on women that closely parallels the current analysis of men for these three countries found that the effects of educational level had changed in all three countries (author citation). This was also the case for the United States (which, however, could not be replicated as there were no comparable data on men). As has been the case for men in many countries, cohabitation was clearly becoming less selective of highly educated women. However, marriage was becoming more selective. These results suggested that women might be assuming more of the provider role, at least in marriage. It is increasingly women with greater capacity to provide who are marrying. This may allow men to enter unions even if they are not the best providers. It is this possibility that we examine in this paper.

\section{Data, Measures, and Analytic Approach}

\section{Data}

Data for Canada and Italy are drawn from two 1995 surveys: the Canadian General Social Survey (GSS), a nationally representative survey of men and women that included approximately 4,800 men aged 15+; and the Italian Fertility and Family Survey, a nationally representative sample of 1,200 men aged 20 to 49. Data for Sweden are taken from the 1992 Swedish Family Survey, a nationally representative sample of 2,300 men from the birth cohorts of 1949, 1959, and 1964. Men in all surveys reported full conjugal histories (all marital and non-marital unions), providing information on their children and families of origin, as well as on a broad range of background characteristics.

\section{Measures}

The analysis uses measures of both stable and time-varying respondent characteristics and activities. We highlight differences in the union formation process for respondents of different ages at the time of the survey (that is, 


\section{The Other Partner: The Changing Role of Good Provider for Men's Union Formation in Industrialized Countries}

successive birth cohorts), who entered the ages of first union formation in different decades. We focus on the changing effects of measures of educational attainment, our main indicator for the good provider role. We also include as control variables time-varying indicators of main activities (work and school enrollment), and presence of children. Time-constant indicators include family structure prior to age 15, number of siblings, and a measure of religious practice. ${ }^{2}$ Table 1 presents the means or proportions on each variable for the three countries, as well as the numbers experiencing each type of union, overall and for each ten-year cohort.

We examine the union formation experience of four birth cohorts. The oldest are those born in 1950 or earlier, most of whom entered their first unions at a time when cohabitation was rare in Canada (105 men had a first cohabitational union compared with 1,265 whose first union was marriage), and nearly nonexistent in Italy, although already common in Sweden. The central cohorts are our major focus. Most of those born in the 1950s (1951-60) and the 1960s (1961-70) had the opportunity to enter some form of union, since the very youngest members of the younger cohort had reached age 25 by the time of the survey. We include an even younger cohort, as well (those born between 1971 and 1980 for Canada and Sweden and between 1971 and 1975 for Italy), in order to provide information on current union formation dynamics among relatively young people (aged 16 to 24). This is a strongly right-censored cohort, because the youngest members could only provide information about their teenage years. Since their presence could distort conclusions in the analysis, we have examined our models excluding this cohort, and the results are robust.

We use the level of a respondent's educational attainment as an indicator of human capital. This measure is time varying, which allows us to estimate both whether a man has attained a given level of education at a given age and whether he is in school at that age, as one indicator of current activity. In all countries, we grouped those who did not complete high school as the lowest category. For Italy and Sweden, the International Standard Classification of Education was used as a basis to generate the variable for our models. Canada presents a somewhat more complex situation. In Quebec, high school ends after 11 th grade and post-secondary education starts with 2-3 years of college before university; in other provinces, high school ends after 12th or 13th grade. We have included those who attended "college" with those who only completed high school in Quebec, consistent with codes used by Statistics Canada. Hence, the highest level in Canada includes those who attended a university; in the other two countries it is those who obtained some education beyond high school. Life events data from questions on the start of employment and work interruptions were used to indicate the years the respondent was employed at 
Frances Goldscheider, Dennis Hogan and Pierre Turcotte

Table 1

Distributions for Men in Canada, Italy and Sweden, 1995 (1992 for Sweden)

\begin{tabular}{|c|c|c|c|}
\hline Variables & Canada & Italy & Sweden \\
\hline \multicolumn{4}{|l|}{ Number of unions: } \\
\hline Marriages (total): & 2140 & 513 & 114 \\
\hline cohort born 1950 or earlier & 1265 & 119 & 67 \\
\hline cohort born 1951-60 & 574 & 231 & 20 \\
\hline cohort born 1961-70 & 288 & 157 & 27 \\
\hline cohort born 1971+ & 13 & 6 & n.a. \\
\hline Cohabitations (total): & 973 & 74 & 1319 \\
\hline cohort born 1950 or earlier & 105 & 3 & 507 \\
\hline cohort born 1951-60 & 368 & 32 & 318 \\
\hline cohort born 1961-70 & 420 & 37 & 494 \\
\hline cohort born 1971+ & 80 & 2 & n.a. \\
\hline \multicolumn{4}{|l|}{ Birth cohort ${ }^{1,2}$} \\
\hline Before 1951 & $37.3 \%$ & $12.7 \%$ & $38.1 \%$ \\
\hline $1951-1960$ & $25.1 \%$ & $27.5 \%$ & $23.0 \%$ \\
\hline$(1961-1970)$ & $23.1 \%$ & $39.6 \%$ & $38.9 \%$ \\
\hline $1971-1980$ & $14.5 \%$ & $20.2 \%$ & n.a. \\
\hline \multicolumn{4}{|l|}{ Educational attainment ${ }^{3}$} \\
\hline Less than high school & $28.6 \%$ & $42.0 \%$ & $25.3 \%$ \\
\hline (High school diploma) & $45.6 \%$ & $49.6 \%$ & $59.6 \%$ \\
\hline College/University & $25.8 \%$ & $8.4 \%$ & $15.1 \%$ \\
\hline \multicolumn{4}{|l|}{ Activity status ${ }^{3}$} \\
\hline School only & $18.5 \%$ & $11.1 \%$ & $15.2 \%$ \\
\hline Work and school & $20.7 \%$ & $4.2 \%$ & $4.5 \%$ \\
\hline (Work only) & $55.0 \%$ & $71.4 \%$ & $65.3 \%$ \\
\hline Neither & $5.7 \%$ & $13.3 \%$ & $15.1 \%$ \\
\hline \multicolumn{4}{|c|}{ Presence of children before union ${ }^{3}$} \\
\hline Birth & $4.4 \%$ & $4.9 \%$ & $3.5 \%$ \\
\hline Conception & $5.9 \%$ & $0.9 \%$ & $4.1 \%$ \\
\hline (No child) & $89.7 \%$ & $94.2 \%$ & $92.4 \%$ \\
\hline \multicolumn{4}{|l|}{ Family origin ${ }^{4}$} \\
\hline (Two-parent family) & $84.9 \%$ & $94.6 \%$ & $88.3 \%$ \\
\hline Ever in lone-family & $10.5 \%$ & $4.2 \%$ & $10.5 \%$ \\
\hline Others & $4.7 \%$ & $1.3 \%$ & $1.2 \%$ \\
\hline \multicolumn{4}{|l|}{ Number of siblings } \\
\hline $0-1$ & $24.8 \%$ & $44.2 \%$ & $39.4 \%$ \\
\hline (2) & $21.5 \%$ & $25.4 \%$ & $27.9 \%$ \\
\hline $3+$ & $53.7 \%$ & $30.4 \%$ & $32.8 \%$ \\
\hline \multicolumn{4}{|l|}{ Religious attendance } \\
\hline Not at all & $46.7 \%$ & $26.8 \%$ & $72.6 \%$ \\
\hline (Sometimes) & $34.9 \%$ & $54.5 \%$ & $23.4 \%$ \\
\hline At least once a week & $18.4 \%$ & $18.7 \%$ & $4.0 \%$ \\
\hline
\end{tabular}

${ }^{1}$ For Italy the youngest cohort is restricted to men born between 1971 and 1975.

${ }^{2}$ For Sweden the categories are composed of women born in 1949, 1954 and 1959, and 1964 and 1969.

${ }^{3}$ For time-dependent variables, the value represents the characteristic of the respondent during the last period before the event, that is one-tenth of a year prior to first union.

${ }^{4}$ The category "Ever in step-family" could not be constructed for Italy or Sweden.

Sources: 1995 General Social Survey, Canada; 1995 Fertility and Family Survey, Italy; 1992 Family Survey, Sweden. 
least part time. In combination, this information allowed us to distinguish those who were in school but not employed, employed but not in school, both in school and employed, and neither in school nor employed for each point in time. Canadian men not only show the highest level of educational attainment of these three countries, they are also the most likely to be enrolled in school. Italian men are low on both of these indicators.

To test for the effects of the presence of fatherhood on men's union formation, we used the information men provided on their fertility histories. The date of birth of children was used to determine when the value for the presence of children had to be changed. The value changed from "childless" to "conception" eight months before the reported date of birth, and changed to "birth" at the birth date. Because the period at risk in our models always ends with a first union, age 35 , or the date of the survey, whichever came first, only conceptions or births that come before the beginning of the first union are considered here.

We have two measures of family background: childhood family structure and the number of siblings. The union formation patterns of both those who lived in a one-parent family at some time before the age of 15 and those who lived in another nontraditional family ${ }^{3}$ in each country will be compared to those who only experienced a stable two-parent family in their childhood. The number of siblings is measured in categories. Few (0-1) and many (3 or more) are contrasted with having two siblings (the reference category).

Religious practice (church attendance) is used rather than religious affiliation. Religious practice seems to provide a better indication of those beliefs that are likely to influence an individual's behavior, although some of the relationship we observe between religiosity and union formation may be a result of past behavior rather than enduring beliefs (Axinn and Thornton, 1995). Religious practice is measured by the number of times a person attends religious services other than weddings, baptisms or funerals. The characteristics analyzed in the models reflect as much as possible the situation of the respondents at the point when they were exposed to the risks of entering into a first union. However, in the absence of further information, church attendance is as reported for the year preceding the survey.

\section{Methods}

We use continuous time, event history analysis techniques (Allison, 1995). General proportional hazard (Cox) models are used to assess the effect of factors influencing the hazard of entering a cohabiting or marital union. The use of the 
Francis Goldscheider, Dennis Hogan and Pierre Turcotte

Cox model allows us not to specify the hazard function, the relationship between the hazard rate and the duration of risk exposure, which is often difficult to specify at the outset. It implies that the duration of exposure has the same effect on each person (the proportionality assumption), meaning that the probability of experiencing the event studied varies over time in the same way for each person. Only the baseline hazard rate varies from one person to another, depending on each person's characteristics. In addition, it allows for the modeling of variables that have values that change over time. We present the results as risk ratios, which represent the relative likelihood of entering a union for someone with the specific characteristic in comparison to someone who would be in the appropriate reference group.

Separate models are built for entry into first cohabitation and entry into first marriage. Each of these events is modeled as a competing risk; that is, upon entering into one of these union forms, the respondent is censored and no longer observed. The underlying assumption is that distinct mechanisms affect the occurrence and timing of each event (Allison, 1995). In our models, people are at risk of entering a first union between the ages of 15 and 35; they are censored as soon as they experience a first union, at age 35, or at the survey date, whichever occurred sooner. The risks of experiencing a first union were measured to each tenth of a year of the risk exposure period.

We model the three countries separately and present these results. This allows us to focus directly on factors important to each country, although we also pooled them together and tested for the significance of the differences between them. We first present the results for all the determinants of first union entry in Canada, Italy and Sweden for the period as a whole. We then examine change, focusing on the evolution of the effects of men's educational attainment. We ask the following question: Does educational attainment exert the same influence on entering a cohabiting or a marital union for each cohort? To answer these questions, we include interaction terms between birth cohort and educational attainment in our final models.

\section{Determinants of Union Formation for All Cohorts}

We present the basic results for the analysis of the determinants of union entry in Table 2. Results are shown separately for each country. Results showing differences among the three countries also appear in the first two columns (below the results for Sweden). Country-specific results show differences by birth cohort, employment, education, family background and religion. These results have theoretical implications that closely parallel those from previous research on women from these countries. We will note these differences. 
The Other Partner: The Changing Role of Good Provider for Men's Union Formation in Industrialized Countries

Table 2

Determinants of Men's First Union Formation, Canada, Italy and Sweden (odds ratios)

\begin{tabular}{|c|c|c|c|c|c|c|}
\hline & \multicolumn{2}{|c|}{ Sweden } & \multicolumn{2}{|c|}{ Italy } & \multicolumn{2}{|c|}{ Canada } \\
\hline & Cohabitation & Marriage & Cohabitation & Marriage & Cohabitation & Marriage \\
\hline \multicolumn{7}{|l|}{ Number of cases: } \\
\hline Events & 1319 & 114 & 74 & 513 & 973 & 2140 \\
\hline Censored & 310 & 1515 & 1048 & 609 & 3237 & 2070 \\
\hline \multicolumn{7}{|l|}{ Birth cohort } \\
\hline Before 1951 & $0.89^{\wedge}$ & $1.73 *$ & $0.18 * *$ & $1.69 * *$ & $0.13 * *$ & $2.25 * *$ \\
\hline $1951-1960$ & 0.95 & 0.97 & 0.97 & $1.66 * *$ & $0.73 * *$ & $1.77 * *$ \\
\hline $1961-1970$ & 1.00 & 1.00 & 1.00 & 1.00 & 1.00 & 1.00 \\
\hline $1971-1980$ & n.a. & n.a. & 0.36 & 0.60 & $1.24^{\wedge}$ & $0.43 *$ \\
\hline \multicolumn{7}{|l|}{ Educational attainment } \\
\hline Less than high school & 1.06 & 1.26 & 1.10 & $1.24 *$ & 0.97 & $0.83 * *$ \\
\hline High school & 1.00 & 1.00 & 1.00 & 1.00 & 1.00 & 1.00 \\
\hline College/University & 1.09 & $1.94 * *$ & $4.33 * *$ & 1.25 & 0.93 & 1.07 \\
\hline \multicolumn{7}{|l|}{ Activity status } \\
\hline School only & $0.65 * *$ & $0.45 *$ & 0.51 & $0.19 * *$ & $0.43 * *$ & $0.34 * *$ \\
\hline Work and School & 0.91 & 0.95 & 0.47 & 0.74 & 0.97 & 0.95 \\
\hline Work only & 1.00 & 1.00 & 1.00 & 1.00 & 1.00 & 1.00 \\
\hline Neither & $0.66 * *$ & 1.04 & 0.87 & $0.53 * *$ & 0.84 & $0.52 * *$ \\
\hline \multicolumn{7}{|l|}{ Children } \\
\hline Birth & $2.54 * *$ & $9.15 * *$ & 0.00 & $3.09 * *$ & $2.60 * *$ & $3.25 * *$ \\
\hline Conception & $6.12 * *$ & $39.45 * *$ & $8.16 * *$ & $30.91 * *$ & $6.17 * *$ & $18.23 * *$ \\
\hline No child & 1.00 & 1.00 & 1.00 & 1.00 & 1.00 & 1.00 \\
\hline \multicolumn{7}{|l|}{ Family origin } \\
\hline two-parent family & 1.00 & 1.00 & 1.00 & 1.00 & 1.00 & 1.00 \\
\hline Ever in lone-family & $1.46 * *$ & 0.82 & $2.41^{\wedge}$ & 1.07 & $1.22^{\wedge}$ & 1.26 \\
\hline Ever in other family & 1.12 & 0.90 & $4.87 *$ & 0.86 & 0.97 & 0.92 \\
\hline \multicolumn{7}{|l|}{ Number of siblings } \\
\hline $0-1$ & 0.96 & 1.21 & $0.44 * *$ & 1.03 & 0.87 & 1.00 \\
\hline 2 & 1.00 & 1.00 & 1.00 & 1.00 & 1.00 & 1.00 \\
\hline $3+$ & 1.97 & $2.67 * *$ & 0.84 & $1.31 *$ & 1.07 & $0.90^{\wedge}$ \\
\hline \multicolumn{7}{|l|}{ Religious attendance } \\
\hline Not at all & $1.21 * *$ & $0.58 *$ & 1.32 & $0.59 * *$ & $1.36 * *$ & $0.85 * *$ \\
\hline Sometimes & 1.00 & 1.00 & 1.00 & 1.00 & 1.00 & 1.00 \\
\hline At least once a week & $0.32 * *$ & $7.08 * *$ & $0.32 *$ & 0.96 & $0.52 * *$ & $1.10^{\wedge}$ \\
\hline \multicolumn{7}{|l|}{ Country (pooled) } \\
\hline Canada & 1.00 & 1.00 & & & & \\
\hline Sweden & $3.44 * *$ & $0.19 * *$ & & & & \\
\hline Italy & $0.20 * *$ & 0.92 & & & & \\
\hline
\end{tabular}

** significant at the $1 \%$ level

* significant at the $5 \%$ level

$\wedge$ significant at the $10 \%$ level

Note: Reference groups for each set of categories are shown with odds ratios of 1.00: birth cohort (1961-1970), educational attainment (high school), activity status (work only). Children (no child), family origin (two-parent family), number of siblings (2), and religious service attendance (sometimes) 
Francis Goldscheider, Dennis Hogan and Pierre Turcotte

\section{Change over Time}

Consistent with the general pattern of the Second Demographic Transition, our results show that the likelihood of entering a first union via cohabitation has increased significantly in all three countries, and the likelihood of entering a first union through marriage has declined. The decline in marriage is even sharper in Canada than in Italy, and is weakest in Sweden, and there are differences in timing. The Swedish decline in marriage is earliest, between the oldest and the next cohort, with no differences between the two later cohorts (1951-60 and 1961-70). The Italian decline does not begin until 10 years later (between the cohorts of 1961-70 and those of 1971-80). For Canadian men, the relative odds of marriage decline throughout the period of observation.

The growth in cohabitation was most rapid in Canada and relatively slow in Sweden, mainly because even the oldest Swedish men in our sample (born in 1949) already had a high propensity to choose cohabitation as their first union. Net of the effects of other determinants, the risks of cohabiting increased by a factor of five in Italy (from .18 to 1.00) between the cohort born before 1951 and the reference cohort (1961-1970). In Canada, there was an increase by a factor of eight between these two cohorts (from .13 to 1.00). This is mainly driven by the increase in non-marital unions in the province of Quebec over the last 20 years (Statistics Canada, 2002).

Italy's increase in cohabitation, however, all came between the oldest and next oldest cohorts. There seems to have been no further increase for the cohort born between 1961-1970, and there is even some suggestion of a decrease for the youngest cohort, although the result is not significant. This change in direction, however, may simply reflect a general delay in union formation for the youngest Italian men, as a similar decline occurred for marriage in this cohort. Italian men are not only less likely to cohabit than Canadian men (as shown in the lower panel, of the pooled results), they are no more likely to marry. Swedish men, in contrast, while less likely to marry than Canadian men, are much more likely to enter cohabiting unions. Most scholars of Swedish union formation agree that the decline in marriage has essentially been offset by the increase in cohabitation (e.g., Bracher and Santow, 1998) and the proportion of people living in couples in Canada has been fairly stable. In Italy, the trends in union formation appear overall to be more negative, as the decline in union formation through marriage has not been offset much if at all by parallel increases in the likelihood of cohabitation. 
The Other Partner: The Changing Role of Good Provider for Men's Union Formation in Industrialized Countries

\section{The Overall Effects of Educational Attainment}

When we consider the average effects of educational attainment over the period as a whole, we see that the pattern of "the good provider" seems to hold in each country, although the effects are relatively weak, and with somewhat differing impacts. In Sweden, college educated men were nearly twice as likely (1.94) to marry directly as men with lower educational levels. Canadians resemble Swedes, with the least educated less likely to marry directly than the more educated; however, the differences are much smaller. In Italy, in contrast, the least educated marry significantly more quickly than those with a high school education (risk ratio of 1.24). The pattern in Italy may be curvilinear, as college educated men are also more likely to marry than those with only a high school education, suggesting some impact of the good provider role, but the difference is not significant. If we can interpret Italy as early/delayed, Canada as actively engaged, and Sweden as a leader, this suggests that marriage is, if anything, becoming more positively selected among more educated men during the second demographic transition.

This speculation is reinforced by the evidence on cohabitation as an alternative route to union entry. The cohabitation results indicate that there is little educational selectivity for entry into this type of union in Sweden and Canada, but in Italy, it is clearly almost totally the province of the college educated. This is also consistent with a "cross-section recapitulating history" interpretation, with Italy looking like the US in the 1960s, when the college educated led the increase in cohabitation, but with the more recent growth drawn increasingly from the less educated. We will soon see by a direct examination of change in the effects of educational attainment, however, whether such an interpretation can be sustained. After reviewing the other overall effects of the factors in this model, we will consider more directly what the effects of education are on union entry for each cohort.

\section{Current Activities, Children, Background Characteristics, and Religiosity}

Current activities. School enrollment was a major deterrent to entering each type of union in all three countries, at least when it was not combined with working, although the coefficient is not significant for cohabitation in Italy. The effect is somewhat stronger for marriage than for cohabitation in all three countries, with the deterring effect on marriage strongest in Italy. To the extent that enrollment precludes providing, these results suggest that this is still an important reason for postponing union entry for men. Of course, when the same result appears for women, the interpretation is that it is family roles that enrollment precludes, despite the high proportions who combine work and 
family roles successfully. What is clear, however, is that for men as for women, school enrollment is an impediment to union entry, and more so for marriage than for cohabitation.

Both Swedish and Canadian men going to school (and not working) are about $40 \%$ as likely to marry as those who were working, while in Italy, school enrollment reduced the odds of marrying to less than $20 \%$ of those who were working. This weaker impact of enrollment in Sweden and Canada than in Italy suggests the possibility of a gradient in school/marriage incompatibility for men that weakens with either more egalitarian gender roles or perhaps more state support for families and/or for students.

Men who combined school enrollment with employment were not significantly less likely to enter either type of union, compared with those employed but not in school. In nearly every case, the coefficients suggest a delaying effect, but clearly, men who combine these two roles look more like workers than students in these results, and perhaps to their prospective partners. Men working full time (but not in school) are more likely to enter a union than any other workschool combination in each of the three countries (which is also pretty much the case for women). Being neither in school nor at work, however, predicts nonentry into marriage only for Italians and Canadians, and non-entry into cohabitation only for Swedes. This is consistent with an interpretation that makes cohabitation the normative route to union formation for Swedes, where there is little perceived difference between the two union forms, but a more deviant union in Italy and Canada.

Children. A child, either impending or already born, always enormously increases the likelihood of entry into both types of union in all three countries. The extreme size of the coefficients reflects the fact that almost no men in any of these surveys reported impregnating a women with whom they never formed a union, a continuing challenge to researchers in this area (Juby and Le Bourdais, 1999; Rendall, et al., 1999). Nevertheless, there are differences in the effects both by type of union and by whether the child is born or impending. The strongest effects are for pregnancies rather than for births, and each increases the likelihood of entering a marital union more strongly than a cohabiting one in all countries. Nevertheless, even considering the weakest effect-that of own children already born on a man's likelihood of entering a cohabiting union-we see that the risk ratios are increased by nearly three times relative to those of men with no reported child for Sweden and Canada. (No Italian men reported children in the interval prior to their beginning to cohabit.)

Childhood family structure. The marital behavior of parents exerts an important influence on the type of first union that their sons will later 
The Other Partner: The Changing Role of Good Provider for Men's Union Formation in Industrialized Countries

experience, with significant effects on cohabitation but not marriage in all three countries. Men who grew up in a stable, two-parent family are significantly less likely to enter a cohabiting union than are their counterparts who either were raised for part of childhood with a single parent or some other family structure (most of which were stepparent forms). The effects are much stronger in Italy, where such breakdowns in the parental generation were rare, than in either Sweden or Canada, where they are much more common. The pattern of effects also differs somewhat between countries, with those most likely to cohabit being from stepparent families in Italy, while sons from single parent families are more likely to choose this union form in Sweden and Canada.

Siblings. The number of siblings has little impact on the risks of cohabitation as a first union, but does seem to have some impact on marriage, particularly in Sweden and Italy. In those two countries, marriage is selective of those who grew up in larger families. Compared with those who grew up with two siblings, men with three or more siblings had $30 \%$ higher odds of marrying in Italy and more than $2 \frac{1}{2}$ times the likelihood of marrying in Sweden. The distributions in Table 1 indicate that such large families are much more rare in Italy and Sweden than in Canada. In Canada, there is some suggestion that those from larger families are less, rather than more likely to marry, but the result is only weakly significant.

Attendance at religious services. People who attend church less frequently are more likely to cohabit and less likely to marry in each country. Religious attendance reduces cohabitation in all three countries, with stronger and fairly similar effects in the two European countries with something of a state church (Sweden and Italy), and weaker effects in Canada. The strongest effects of religious attendance on marriage are for Sweden, where the coefficients are quite dramatic. The most religious Swedish men are more than seven times as likely to marry as those who attend church on an irregular basis, and more than ten times as likely as those who do not attend much at all.

We found that this effect has been strengthening across cohorts (data not presented). Religious involvement had more impact among men in the most recent cohorts compared with men who entered unions in the 1970s and early 1980s. This result is consistent with other results indicating that family-related values are having increasing impact in the union formation process (Sassler and Goldscheider 2004). 
Francis Goldscheider, Dennis Hogan and Pierre Turcotte

\section{The Changing Effect of Educational Attainment}

But is the effect of education on union formation also changing? Is marriage continuing to select men with the greatest earning potential? In this section we address this question directly, considering evidence for change in each of these three countries. Previous research on these countries found that women entering into cohabitations became less selective of those with a high education (Goldscheider, Turcotte, and Kopp, 2001). This turns out to be the case for men, as well, and also for men's entry into marriage.

Our results focus on the changing effects of educational attainment on first union formation, distinguishing cohabitation and marriage as competing risks. Table 3 presents changes in the effects of educational attainment on the probability that three cohorts of Canadian, Italian and Swedish men enter cohabiting or marital unions. Change is tested by looking at interaction effects between educational categories and the birth cohorts. This allows us to observe differences in the effects of educational attainment between cohorts. As before, these are presented as relative risk ratios, but this time we focus on the three educational levels within each birth cohort. (The intermediate level of education in each cohort is the reference category for education, 1961-70 is the reference category for birth cohort.) Our emphasis is on whether and if so, how, the effects of education change from one cohort to another. ${ }^{4}$ This allows us to follow the trends over time in the effects of educational attainment on union formation, netting out the often-overwhelming effect of cohort change. In each of these analyses, the effects of the other explanatory variables have been controlled. We omit the youngest birth cohort (1971+), among whom those in the highest educational category have had almost no time to enter unions in Italy and Canada, and for which we have no cases for Sweden.

In general, the results show consistent changes in the effects of educational attainment on both marriage and cohabitation for all three countries. In each country, the effect of education was positive for marriage for the oldest cohort, with all significant differences in relative odds showing increases by level of education. However, the positive effect of higher education on marriage attenuated among the younger cohorts. The pattern was the same for cohabitation, although Italy is an exception, for which no attenuation is evident. Results suggest that the role of education in signaling men's good provider status has weakened, or perhaps that role itself has become less important in the partner market.

The most poorly educated in the earliest cohort $(<1951)$ were much less likely to enter a cohabitation in all three countries than the reference cohort (1961-1970), significantly so in Sweden and Canada, and with an insignificant coefficient of 
The Other Partner: The Changing Role of Good Provider
for Men's Union Formation in Industrialized Countries

Table 3

Changing Effect of Educational Attainment on Men's First Union Formation, by Union Type and Birth Cohort, Canada, Italy and Sweden, 1995 (1992 for Sweden) ${ }^{1}$

\begin{tabular}{|c|c|c|c|}
\hline \multirow[b]{2}{*}{ Cohort } & \multicolumn{3}{|c|}{ Odds ratios for the effect of educational attainment } \\
\hline & Less than high school & (High school diploma) & College/University \\
\hline & \multicolumn{3}{|c|}{ Canada } \\
\hline \multicolumn{4}{|l|}{ Cohabitation } \\
\hline Before 1951 & $0.48 *$ & 1.00 & $1.54 *$ \\
\hline $1951-1960$ & 1.17 & 1.00 & 0.96 \\
\hline $1961-1970$ & 1.01 & 1.00 & 0.82 \\
\hline \multicolumn{4}{|l|}{ Marriage } \\
\hline Before 1951 & $0.81 \wedge$ & 1.00 & 1.10 \\
\hline $1951-1960$ & 0.84 & 1.00 & 1.04 \\
\hline $1961-1970$ & 1.17 & 1.00 & 1.10 \\
\hline & \multicolumn{3}{|c|}{ Italy } \\
\hline \multicolumn{4}{|l|}{ Cohabitation } \\
\hline Before 1951 & 0.25 & 1.00 & 1.48 \\
\hline $1951-1960$ & 0.94 & 1.00 & 4.07 \\
\hline $1961-1970$ & 1.37 & 1.00 & 4.80 \\
\hline \multicolumn{4}{|l|}{ Marriage } \\
\hline Before 1951 & $0.57 * *$ & 1.00 & 0.86 \\
\hline $1951-1960$ & 1.37 & 1.00 & 1.36 \\
\hline \multirow[t]{2}{*}{$1961-1970$} & 1.55 & 1.00 & 1.11 \\
\hline & \multicolumn{3}{|c|}{ Sweden } \\
\hline \multicolumn{4}{|l|}{ Cohabitation } \\
\hline Before 1951 & $0.89 \wedge$ & 1.00 & 0.95 \\
\hline $1951-1960$ & 1.25 & 1.00 & 1.41 \\
\hline $1961-1970$ & 1.18 & 1.00 & 1.05 \\
\hline \multicolumn{4}{|l|}{ Marriage } \\
\hline Before 1951 & 1.20 & 1.00 & 1.91 \\
\hline $1951-1960$ & 1.09 & 1.00 & $4.36 *$ \\
\hline $1961-1970$ & 1.85 & 1.00 & 0.98 \\
\hline
\end{tabular}

** Educational category is significantly different from the same category for the 1961-70 cohort at .01

* Educational category is significantly different from the same category for the 1961-70 cohort at .05

$\wedge$ Educational category is significantly different from the same category for the 1961-70 cohort at .10

${ }^{1}$ Regressions controlled for the other variables in Table 2.

Note: The reference group for the interaction tests of (educational attainment * cohort) for each country is (high school $* 1961$ cohort)

Sources: 1995 General Social Survey, Canada; 1995 Fertility and Family Survey, Italy; 1992 Family Survey, Sweden. 
.19 in Italy. University men in the earliest cohort in Canada were substantially more likely to cohabit than less educated men. However, cohabitation is no longer a distinctive feature of college-educated men among later Canadian cohorts, and is not in evidence at all in Sweden, which has a longer history of high levels of cohabitation than Canada. High education and cohabitation are still linked for Italian men, and if anything this linkage has intensified. This is consistent with the very low levels of cohabitation in Italy, and the likelihood that the most educated have led the early growth in this union form in both Italy and Canada.

The pattern is pretty much the same for marriage, except that it is Sweden where change is less clear. In Canada and Italy, the least educated were the least likely to marry among the older cohorts, a pattern that has attenuated for younger cohorts. There is some suggestion for Sweden that marriage is more likely among the least educated in the youngest cohort, as in the other two countries, but nothing is significant and marriage results for Sweden are very unstable, particularly for the youngest cohort, as almost no one enters marriage directly.

As we noted earlier, these changes parallel those previously found for women in these countries, at least for cohabitation. Among Canadian, Italian, and Swedish women, the more educated had become either less positively or more negatively selected into cohabitation, and this was also the case for the United States. For marriage, in contrast, it is the more educated women who have become somewhat more positively selected, more resembling the good provider men who were entering marriage in the past. This suggests that the growth in women's human capital is an increasingly important factor in their decision to commit to a stable relationship, which marriage provides more clearly than cohabitation.

\section{Discussion and Conclusions}

While much attention has focused on the "retreat from marriage" on the part of women, less research has examined men's decisions to form intimate unions. This analysis reexamines well-established assumptions regarding the unchanging nature of the "good provider" role on men's union entry. We present results for four cohorts of men in three countries at different stages of the second demographic transition.

Our findings lead us to conclude that over the past three decades, the connection between men's economic status and both marriage and cohabitation has weakened in all three nations-Italy, Canada, and Sweden. Higher education (our measure of earnings potential) has become substantially less predictive of both forms of union entry. A high level of education thus is no longer a 


\section{The Other Partner: The Changing Role of Good Provider for Men's Union Formation in Industrialized Countries}

prerequisite for forming a union. The results show general patterns of change that characterize all three countries, suggesting that some general process is sweeping though each of them, leading to substantial convergence among them. However, it is also clear that there are specific situations that make these countries unique.

What are the general patterns of change? The most dramatic is one rarely discussed when theories of union formation are proposed, as it involves cohabitation. This form of union has grown substantially in all three countries (although most of the increase in cohabitation in Sweden began before that in other nations). If current trends continue, there will be a convergence toward high levels of cohabitation as the first union across these countries. This is, of course, well known. Our results indicate, however, that the characteristics of those who chose cohabitation as a first union have also changed in systematic ways in each of these countries. The early innovators vis à vis cohabitation generally were the more educated, with less educated people catching up only later. The declining impact of high education on entry to cohabitation is consistent with leader-follower dynamics, as the innovators in the early growth in cohabitation were the more educated.

The declining impact of high education on entry to marriage, in contrast, has a very different theoretical import, as it suggests that the entire apparatus of gender roles underlying marriage, in which men needed to be providers and women did not, is becoming less salient. This finding for men complements the earlier work on women, which indicated that the forces shaping the entry to marriage were changing in opposite ways to those for cohabitation. Among women, the more educated have been resisting the decline in marriage more than the less educated, particularly in Canada. In other words, as women have become more educated, they have become more willing to rely on their own earnings capacity to guarantee family economic well being, permitting them to marry men with a broader range of earnings potential. In essence, it seems that a promise of financial security remains a prerequisite for marriage, but this prerequisite can be met by either spouse. Further, men do not seem to use their human capital characteristics to marry rather than cohabit. Women, however, were found to be increasingly using their human capital resources to marry rather than cohabit in their first union.

It seems that the simple patterns, based on separate and symmetrical roles for men and women, are taking new shapes with the growth in cohabitation and possible changes in the meanings and commitments underlying family life. It is not at all clear whether a new, but equally simple pattern will emerge. It is unlikely that our understanding will be greatly advanced until we know as much about changes in men's union formation patterns as we are beginning to learn 
Francis Goldscheider, Dennis Hogan and Pierre Turcotte

about women's. What is important is that we at least carry out our analyses of family life during a rapidly changing period with an awareness that not only are the behaviors we are studying changing but also the reasons for doing so.

\section{Acknowledgements:}

Paper presented at the 2002 annual meeting of the Population Association of America, Atlanta, Georgia, session on "Changing Gender Roles and the Family" by Stephen Nock. We gratefully acknowledge support for this research from the National Science Foundation Grant SBR-89807517 and the National Center for Child Health and Human Development to the Brown University Population Studies and Training Center (grant P30HD28251), as well as support from the Statistics Canada Research Sabbatical Program. We also wish to thank the Advisory Group of the FFS programme of comparative research for its permission to use the FFS data on which this study is based.

\section{End Notes:}

1. The other studies in this series did not control for educational enrollment, with the result that educational attainment often had a negative effect on union formation; other studies only examined the effects of educational attainment in complex interactions with age (Corijn and Klijzing 2001).

2. We also examined our results controlling for region of residence, incountry birth, and a measure of language (French versus other mother tongues) for Canada and region for Italy. Our results were robust to their omission.

3. Most "other" nontraditional families were stepfamilies in Canada and Sweden; stepfamilies were not distinguished in Italy.

4. The coefficients in Table 3 show the effect of combining the coefficients for education and the interaction coefficients of education and cohort 
The Other Partner: The Changing Role of Good Provider for Men's Union Formation in Industrialized Countries

\section{References:}

Axinn W. and Thornton A. 1995. The Influence of Parents' Marital Dissolution on Children's Attitudes Toward Family Formation, Demography, 33: $66-81$

Becker G. 1991. A Treatise on the Family (enlarged edition). Cambridge, MA, Harvard University Press.

Bernard J. 1981. The Good Provider Role: Its Rise and Fall, American Psychologist, 36: 1-12.

Bernard J. 1972. The Future of Marriage. NY: World Publishing Company.

Blom S. 1994. Marriage and Cohabitation in a Changing Society: Experience of Norwegian Men and Women Born in 1945 and 1960, European Journal of Population, 9: 143-173.

Bracher M. and Santow G. 1998. Economic Independence and Union Formation in Sweden, Population Studies, 52: 275-294.

Bumpass L, Sweet J. 1989. National Estimates of Cohabitation, Demography 26: $615-25$

Bumpass L, Sweet J, Cherlin A. 1991. The Role of Cohabitation in Declining Rates of Marriage, Journal of Marriage and the Family 53: 913-927.

Burtless G. 1990. A Future of Lousy Jobs? The Changing Structure of U.S. Wages. Washington, DC: The Brookings Institution.

Castiglioni M, Dalla Zuanna G. 1994. Innovation and Tradition: Reproductive and Marital Behaviour in Italy in the 1970s and 1980s, European Journal of Population, 10: 107-141.

Clarkberg M, Stolzenberg R, Waite L. 1995. Attitudes, Values, and Entrance into Cohabitational versus Marital Unions, Social Forces, 74: 609-632.

Corijn, M. 2001. Transition to Adulthood in Flanders (Belgium), in Corijn and Klijzing, eds. Transitions to Adulthood in Europe. Klewer Academic Publishers. Pp. 103-130.

Corijn, M. and Klijzing, E., (Eds.). 2001. Transitions to Adulthood in Europe. Klewer Academic Publishers. 
Francis Goldscheider, Dennis Hogan and Pierre Turcotte

Corijn, M. and Klijzing, E. 2001. Transitions to Adulthood in Europe, in Corijn and Klijzing, (Eds.). Transitions to Adulthood in Europe. Klewer Academic Publishers. Pp. 313-340.

Dixon R. 1978. Late Marriage or Non-marriage as Demographic Responses: Are They Similar?, Population Studies 32: 449-466.

Furstenberg, F.F., Jr. 1996. The future of marriage. American Demographics, June, 34-40.

Goldscheider F, Turcotte P, Kopp A. 2001. The Changing Determinants of Women's First Union Formation in Industrialized Countries: The United States, Canada, Italy and Sweden. Genus, pp. 107-134.

Goldscheider F, Waite L. 1991. New Families, No Families? The Transformation of the American Home. Berkeley, CA: University of California Press.

Hajnal J. 1982. Two Kinds of Preindustrial Household Formation Systems, Population and Development Review, 8: 449-494.

Hogan D. 1978. The Effects of Demographic Factors, Family Background, and Early Job Achievement on Age at Marriage, Demography, 15: 161-75.

Huinink J. 1995. Education, Work, and Family Patterns of Men: The Case of West Germany, in Blossfeld (ed.) The New Role of Women: Family Formation in Modern Societies. Boulder: Westview Press. Pp. 247263.

Juby H, Le Bourdais C. 1999. Where Have All the Children Gone? Comparing Mothers' and Fathers' Declarations in Retrospective Surveys, Canadian Studies in Population, 26: 1-20.

Landale N. 1989. Agricultural Opportunity and Marriage: The United States at the Turn of the Century, Demography, 26: 203-18.

Landale N, Tolnay S. 1991. Group Differences in Economic Opportunity and the Timing of Marriage: Blacks and Whites in the Rural South, 1910, American Sociological Review, 56: 33-45. 
The Other Partner: The Changing Role of Good Provider for Men's Union Formation in Industrialized Countries

Le Bourdais C, Marcil-Gratton N. 1996. Family Transformations Across the Canadian/American Border: When the Laggard Becomes the Leader, Journal of Comparative Family Studies, 27: 415-436.

Levy F. 1995. Incomes and Income Inequality, in R. Farley (ed.), State of the union: America in the 1990s: economic trends. New York: Russell Sage Foundation. Pp. 1-58.

Lichter D, Anderson R. 1995. Marriage Markets and Marital Choice, Journal of Family Issues, 16: 412-432.

Lichter D, LeClere F, McLaughlin D. 1991. Local Marriage Markets and the Marital Behavior of Black and White Women, American Journal of Sociology, 96: 843-67.

Lloyd K, South S. 1996. Contextual Influences on Young Men's Transition to First Marriage, Social Forces, 74: 1097-1119.

Mayer K. 2001. The Paradox of Global Social Change and National Path Dependencies: Life Course Patterns in Advanced Societies, pp. 89-110 in Woodward A. and Kohli M (eds.) Inclusions-Exclusions. London: Routledge.

Mills M, Blossfeld H-P, Klijzing E. 2005. Globalization, uncertainty and changes in the early life course, in Blossfeld, H.-P., E. Klijzing, M. Mills and K. Kurz (eds.) (Eds.). Globalization, uncertainty and youth in society. London: Routledge. Pp. 1-24.

Ongaro, F. 2001. Transition to Adulthood in Italy, in Corijn and Klijzing, eds. Transitions to Adulthood in Europe. Klewer Academic Publishers. Pp. 173-207

Oppenheimer V. 1988. A Theory of Marriage Timing, American Journal of Sociology, 94: 563-91.

Oppenheimer V. 2003. Cohabiting and Marriage During Young Men's Career Development, Demography, 40: 127-149.

Oppenheimer V, Blossfeld H-P, Wackerow A 1995. United States of America, in H. Blossfeld (Ed.), The New Role of Women. Boulder: Westview Press. Pp. 150-173. 
Francis Goldscheider, Dennis Hogan and Pierre Turcotte

Oppenheimer V, Kalmijn M, Lim N. 1996. Men's Career Development and Marriage Timing During a Period of Rising Inequality, Demography, 34: $311-330$

Rendall M, Clarke L, Peters H, Ranjit N, Verropoulou G. 1999. Incomplete Reporting of Male Fertility in the United States and Britain: A Research Note, Demography, 36: 135-144.

Santow G, Bracher M. 1994. Change and Continuity in the Formation of First Marital Unions in Australia, Population Studies, 48: 475-496.

Sassler S, Goldscheider F. 2004. Revisiting Jane Austen's Theory of Marriage Timing: Union Formation Among American Men in the Late 20th Century, Journal of Family Issues, 25: 139-166.

Sassler S, Schoen R. 1999. The Effect of Attitudes and Economic Activity on Marriage, Journal of Marriage and the Family, 61: 147-159.

Statistics Canada. 2002. Changing Conjugal Life in Canada. Ottawa. Catalogue no. 89-576-XIE

Sweeney M. 2002. Two Decades of Family Change: The Shifting Economic Foundations of Marriage, American Sociological Review, 67: 132-147.

Thornton A, Young-DeMarco L. 2002. Four Decades of Trends in Attitudes Toward Family Issues in the United States: The 1960s Through the 1990s, Journal of Marriage and the Family, 63: 1009-1037.

Thornton A, Axinn W, Teachman J. 1995. The Influence of Educational Experiences on Cohabitation and Marriage in Early Adulthood, American Sociological Review, 60: 762-774.

Turcotte P, Goldscheider F. 1998. Evolution of Factors Influencing First Union Formation in Canada, Canadian Studies in Population, 28: 145-173.

van de Kaa, D. 1987. Europe's second demographic transition. Population Bulletin (Washington, DC), 42: 1-47.

Wall R. 1983. The Household: Demographic and Economic Change in England, 1650-1970, In R. Wall (ed.), Family Forms in Historic Europe. Social Science Research Council, 1983. 